OPEN ACCESS

Edited by:

Carlito Baltazar Tabelin, University of New South Wales,

Australia

Reviewed by:

Edward Kavazanjian,

Arizona State University, United States

Ljubica Tasic,

State University of Campinas, Brazil

${ }^{*}$ Correspondence:

Sivakumar Gowthaman gowtham1012@outlook.com

Specialty section:

This article was submitted to

Toxicology, Pollution and the

Environment,

a section of the journal

Frontiers in Environmental Science

Received: 02 April 2021 Accepted: 16 June 2021

Published: 12 July 2021

Citation:

Gowthaman S, Chen M, Nakashima K and Kawasaki S (2021) Effect of Scallop Powder Addition on MICP Treatment of Amorphous Peat. Front. Environ. Sci. 9:690376. doi: $10.3389 /$ fenvs.2021.690376

\section{Effect of Scallop Powder Addition on MICP Treatment of Amorphous Peat}

\author{
Sivakumar Gowthaman ${ }^{1 *}$, Meiqi Chen ${ }^{2}$, Kazunori Nakashima ${ }^{1}$ and Satoru Kawasaki ${ }^{1}$ \\ ${ }^{1}$ Division of Sustainable Resources Engineering, Faculty of Engineering, Hokkaido University, Sapporo, Japan, ${ }^{2}$ Division of \\ Sustainable Resources Engineering, Graduate School of Engineering, Hokkaido University, Sapporo, Japan
}

Peat is one of the most challenging and problematic soils in the fields of geotechnical and environmental engineering. The most critical problems related to peat soils are extremely low strength and high compressibility, resulting in poor inhabitancy and infrastructural developments in their vicinity. Thus far, peat soils were stabilized using Portland cement; however, the production of Portland cement causes significant emission of greenhouse gases, which is not environmentally desirable. Microbial-induced carbonate precipitation (MICP) is an innovative technique for improving the mechanical properties of soil through potentially environmentally friendly processes. This article presents a laboratory study carried out with the aim of investigating the viability and effect of scallop shell powder (SSP) on enhancing the mechanical properties of the MICP-treated amorphous peat. The hypothesis was that the distribution of SSP (as-derived calcite particles) would (i) provide more nucleation sites to precipitates and (ii) increase the connectivity of MICP bridges to facilitate mineral skeleton to amorphous peat, accompanied by an increase in its compressive strength. Specimens were treated at varying combinations of SSP and MICP reagents, and the improvement was comprehensively assessed through a series of unconfined compression tests and supported by microscale and chemical analyses such as scanning electron microscopy, energy-dispersive X-ray analysis, and X-ray diffraction analysis. The outcomes showed that incorporating SSP in MICP treatment would be a promising approach to treat amorphous peat soils. The proposed approach could improve the unconfined compressive strength by over 200\% after a 7 -day curing period, while the conventional MICP could not exhibit any significant improvements.

\section{Keywords: microbial-induced carbonate precipitation (MICP), amorphous peat, scallop shell powder, stabilization,} unconfined compressive strength

\section{INTRODUCTION}

Peat, one of the most problematic soils, is formed by the accumulation of partly or fully decomposed plant remains in the absence of oxidative environment (O'Kelly, 2015). Peatlands are present in various parts of the world, and their coverage has been estimated to be nearly $8 \%$ of the Earth's surface (which is equivalent to 4.23 million $\mathrm{km}^{2}$ ) (Mesri and Ajlouni, 2007; Xu et al., 2018). The problem related to peat deposits is their low bulk density, low shear strength, and extreme compressibility (Huat et al., 2014; Paul and Hussain, 2020). Because of poor engineering characteristics, infrastructure developments on peatlands often pose risks regarding bearing capacity failure and excessive total and/or differential settlements. At the same time, the avoidance of peatlands can no longer be a solution due to increasing scarcity of suitable grounds for constructions. Therefore, to enable infrastructural growth and inhabitancy in the 
vicinity of peatlands, the soil requires to be treated in an appropriate manner considering both geotechnical properties and design requirements.

Since a couple of decades ago, a number of mechanical and chemical methods were introduced for improving the geotechnical properties of peat. One less complicated method was excavation. During excavation, deposits were excavated and replaced with firm materials (such as sand) to enhance the bearing capacity of peatlands (Zulkifley et al., 2014). Instead, when the peat occupied over $5 \mathrm{~m}$ in depth, pile foundations were driven to the bedrocks/firm strata through the peat. Although the pile supports could largely minimize the settlement issues, the infrastructures still underwent differential settlements and tilting (Huat, 2004). Additionally, by using the experience gained, researchers developed several other methods including prefabricated vertical drains (PVD), sand drains, and preloading methods to accelerate the consolidation process, thus improving the load-bearing capacity of peatlands (Hayashi et al., 2011; Rowe and Taechakumthorn, 2008). The biggest challenge in the former techniques was unaffordability, as they required high performance equipment and substantial energy. In the meantime, chemical binders (e.g., Portland cement (PC), fly ash, blast furnace slag, bentonite, and gypsum) were also used to improve the usability of the peat (Aiken et al., 2020; Hebib and Farrell, 2003; Paul and Hussain, 2020; Zulkifley et al., 2014). The PC was the most recommended binder among them, involving hydration processes to harden the peat (Kalantari, 2010; Paul and Hussain, 2020). However, as indicated by Benhelal et al. (2012), a drawback of most of the binders is that their production largely contributes to environmental issues by releasing $\mathrm{CO}_{2}$ and $\mathrm{SO}_{2}$ gases. From the literature survey, one thing is clearly perceived that there is a high societal requirement for new stabilization practices in conjunction with technological developments.

As an alternative, microbial-induced carbonate precipitation (MICP), a newly developed soil improvement technology, has drawn a great deal of interest among researchers (Achal and Kawasaki, 2016; Ivanov et al., 2019; Omoregie et al., 2020). The mechanism of MICP involves nonpathogenic bacteria and their metabolism for stabilization, in a way similar to naturally occurring biomineralization process. The urease enzymes localized in the bacteria (in either cell membrane or cytoplasm) exert catalytic function, that is, hydrolysis of urea (see Eq. 1). In an aqueous environment, the products (carbonic acid and ammonia) equilibrate to form ammonium $\left(\mathrm{NH}_{4}^{+}\right)$and bicarbonate ions $\left(\mathrm{HCO}_{3}^{-}\right.$) (Eqs 2, 3, respectively). Production of hydroxyl $\left(\mathrm{OH}^{-}\right)$ions increases the $\mathrm{pH}$ of the reaction medium and leads to the speciation of carbonate ions $\left(\mathrm{CO}_{3}^{2-}\right)$ (Eq. 4), followed by the crystallization of $\mathrm{CaCO}_{3}$ in the presence/supply of dissolved calcium (as in Eq. 5). The precipitates then cement the soil particles at interparticle contacts (where the bacterial cells provide nucleation) to increase the strength and stiffness of the matrix (DeJong et al., 2010; Lin et al., 2016).

$$
\begin{gathered}
\mathrm{H}_{2} \mathrm{~N}-\mathrm{CO}-\mathrm{NH}_{2}+2 \mathrm{H}_{2} \mathrm{O} \stackrel{\text { urease }}{\longrightarrow} \mathrm{H}_{2} \mathrm{CO}_{3}+2 \mathrm{NH}_{3}, \\
\mathrm{NH}_{3}+\mathrm{H}_{2} \mathrm{O} \leftrightarrow \mathrm{NH}_{4}^{+}+\mathrm{OH}^{-},
\end{gathered}
$$

$$
\begin{gathered}
\mathrm{H}_{2} \mathrm{CO}_{3} \leftrightarrow \mathrm{HCO}_{3}^{-}+\mathrm{H}^{+}, \\
\mathrm{HCO}_{3}^{-}+\mathrm{OH}^{-} \leftrightarrow \mathrm{CO}_{3}^{2-}+\mathrm{H}_{2} \mathrm{O}, \\
\mathrm{Ca}^{2+}+\mathrm{CO}_{3}^{2-} \rightarrow \mathrm{CaCO}_{3}(\downarrow),
\end{gathered}
$$

A vast majority of MICP studies, thus far, focused on improving sandy soils, while the attention given on different soils (such as clay, peat) is very limited. Following the study carried out by Whiffin (2004), Sporosarcina pasteurii were mostly involved in subsequent studies to evaluate various physical and mechanical properties of MICP-treated sandy soils in various scales (Cheng and Cord-Ruwisch, 2014; Feng and Montoya, 2016; van Paassen et al., 2010). Few studies could extend the technique for stabilizing soft soils. For instance, Islam et al. (2020) evaluated the effect of the clay content on MICP treatment. Their outcomes indicated that although the formation of calcium carbonate could marginally increase the unconfined compressive strength (UCS), the values attained after saturation were far below $50 \mathrm{KPa}$. Relatively similar outcomes were also reported by Sato et al. (2016) for the MICP-treated peat, where their UCS values after one month curing were between 5 and $30 \mathrm{kPa}$. In another case, the treated peat exhibited a shear strength of around $20 \mathrm{kPa}$ corresponding to the $20 \% \mathrm{CaCO}_{3}$ content (Canakci et al., 2015), while the sandy soils were shown to have strength values in the $\mathrm{MPa}$ range for the same precipitation content (Gowthaman et al., 2020; Sharma et al., 2021; van Paassen et al., 2010). It should be noted that most of the existing studies that focused on improving the peat were unable to meet the minimal strength requirement, that is, $50 \mathrm{kPa}$, which is the threshold UCS required to allow the transport of dump trucks over the peatland. Smaller pore throat size is one major reason for the low strength achieved in MICPtreated peat soils because it restricts the transport/penetration of bacterial cells into the soil, thus affecting the efficacy of the typical injection-based MICP approach (Mitchell and Santamarina, 2005). Particularly, the abovementioned challenge is more pronounced for amorphous peat, which has lower open pore structures and hydraulic conductivity compared to those of fibrous peat. Following the proposal by Keykha et al. (2012), Safdar et al. (2021) involved electrokinetic injection to overcome the limitations related to the rate of transport in peat soils. In due course, Chen et al. (2021) proposed and demonstrated a dry mixing approach for effectively treating the peat. In fact, the organic particles are weak in nature. When the loading is imposed, they rapidly undergo localized failure rather than the failure at $\mathrm{CaCO}_{3}$ bridges (Canakci et al., 2015). It is therefore apparent that MICP cementation alone may not be effective for satisfactorily stiffening the skeleton and enhancing the mechanical properties of the peat.

Keeping previous studies in mind, this research work was designed for the purpose of evaluating the applicability and effects of scallop shell powder (SSP) in the MICP treatment of amorphous peat. The hypothesis was that the addition of calcium carbonate-rich SSP would lead to an increased connectivity and the formation of mineral skeleton throughout the peat, accompanied by an increase in its strength. The abovementioned hypothesis was assessed through unconfined compression tests, scanning electron microscopy (SEM), 
energy-dispersive X-ray (EDX) analysis, and X-ray diffraction (XRD) analysis. All the results obtained in this study are discussed comprehensively in the subsequent sections.

\section{MATERIALS, METHODS, AND PROCESSES}

\section{Characteristics of Peat}

In Japan, peat deposits are mainly found in the Hokkaido island (the northmost island of Japan's four main islands), yet a minor distribution exists in other islands as well. As depicted in Supplementary Figure $\mathbf{S 1}$, around $2,000 \mathrm{~km}^{2}$ is occupied by peat deposits in Hokkaido, which has been reported to be approximately $6 \%$ of the flat land in Hokkaido (Noto, 1991). The peat used in this study was obtained from Tomikawa, Hokkaido, Japan (indicated in Supplementary Figure S1). The obtained samples were carefully sealed in plastic bags, transported to the laboratory, and stored at $4^{\circ} \mathrm{C}$ without moisture loss. The fundamental physical and chemical properties determined based on the Japanese Industrial Standards (JIS) are presented in Table 1. The soil was found to be a mixture of minerals and organic content in its as-received state. The dark greyish color with no visible plant structure and mushy consistency indicated the sapric humification scale, that is, "Pta" subgroup according to the Organic Soil Classification System (Huat, 2004; Zulkifley et al., 2013). Based on its organic content (>20\%), the soil was identified as the clayey (clay $>50 \%$ ) amorphous peat.

\section{Scallop Shell Powder}

The powder from scallop shell (Mizuhopecten yessoensis) used in this study was commercially obtained from the Aomori Ecological Recycle Industrial Association (Aomori prefecture, Japan). The particle size distribution curve of SSP is presented in Figure 1. The mean particle diameter of SSP was approximately $0.125 \mathrm{~mm}$. Additionally, the chemical properties of the SSP are listed together with testing standards in Table 2. As expected, the SSP contained majorly the calcium component. It is worthwhile noting that silver and copper, which typically possess antibiotic properties, were not detected in SSP $(<0.01 \%)$. The $\mathrm{pH}$ of the SSP was around 10.0 at room temperature.

\section{Ureolytic Bacteria}

Sporosarcina sp. (SIID 33506), an alkaliphilic soil bacteria of biosafety level 1, were used in this study to induce MICP cementation. The bacteria were previously isolated from the Iwamizawa peatland (Hokkaido, Japan) and are known to have reliable enzymatic performance. Ammonium-yeast extract media (ATCC 1376) were used to culture the bacteria, which consisted of $10 \mathrm{~g} / \mathrm{L}$ ammonium sulfate, $20 \mathrm{~g} / \mathrm{L}$ yeast extract, and $15.7 \mathrm{~g} / \mathrm{L}$ tris buffer. The growth media were inoculated with the bacteria stock culture and subjected to shaking incubation at $25 \pm$ $1^{\circ} \mathrm{C}$ and $160 \mathrm{rpm}$. When the population of the bacteria $\left(\mathrm{OD}_{600}\right)$ reached the optimum value $\left(\mathrm{OD}_{600}\right.$ of $4.0 \pm 0.2$, typically after $48 \mathrm{~h}$ ), the bacteria culture was centrifuged at $8,000 \mathrm{rpm}$ for $5 \mathrm{~min}$, and the supernatant volume was adjusted to achieve the desired population level, $\mathrm{OD}_{600}$ of $8.0 \pm 0.1$. The urease activity of the bacteria was approximately $1.0 \pm 0.3 \mathrm{U} / \mathrm{mL} / \mathrm{OD}_{600}$ at $25 \pm 1{ }^{\circ} \mathrm{C}$.
TABLE 1 | Basic physiochemical characteristics of amorphous peat.

\begin{tabular}{lc}
\hline Property & Value \\
\hline Specific gravity $\left(\mathrm{g} / \mathrm{cm}^{3}\right)$ & 2.21 \\
Natural gravimetric water content $(\% \mathrm{w} / \mathrm{w})$ & 119.55 \\
$\mathrm{pH}$ & 2.50 \\
Organic matter content $(\% \mathrm{w} / \mathrm{w})$ & 39.01 \\
Natural $\mathrm{CaCO}_{3}$ content $(\%)$ & $0.9 \pm 0.1$
\end{tabular}

\section{Preparation and Treatment}

MICP was introduced to the peat by mechanical mixing. Each specimen was prepared separately according to the test condition. A certain quantity of the peat soil ( $300 \mathrm{~g} /$ specimen) was placed into the mechanical mixer (Figure 2A), followed by the addition of $\mathrm{CaO}_{2}$, MICP resources (calcium chloride, urea, and nutrient broth), bacteria culture solution, and SSP in the abovementioned sequence. Each specimen was subjected to identical mixing conditions for a total mixing duration of $6 \mathrm{~min}$. As mentioned, $\mathrm{CaO}_{2}$ was introduced at the first stage of mixing to elevate the $\mathrm{pH}$ of the acidic peat. Basically, $\mathrm{CaO}_{2}$ is an alkali material, widely used as a fertilizer product and cheaply found in the market; therefore, $\mathrm{CaO}_{2}$ was sustainably used as the $\mathrm{pH}$ adjuster, providing a favorable chemical condition for the urea hydrolysis reaction. Calcium chloride, urea, and nutrient broth were introduced to the soil at the intermediate stage of mixing. Afterward, $20 \mathrm{ml}$ (per 300 g peat) of the prepared bacteria culture was added and mixed uniformly. SSP was introduced to the soil at the final stage. It should be noted that all the substances except the bacteria culture were introduced at their solid stage and allowed to dissolve in the excess moisture of peat soils. The mixture was then placed into the cylindrical reaction-resistant molds $(5 \mathrm{~cm}$ in diameter and $10 \mathrm{~cm}$ in height) (Figure 2B) in three equivalent layers, and each layer was compacted using a $2.2 \mathrm{lb}$ hammer with 25 evenly distributed blows. The surface of the specimens was covered using a polythene wrap to avoid moisture loss due to evaporation, and then subjected to curing into the incubator of $25^{\circ} \mathrm{C}$.

\section{Mix Designs}

Table 3 summarizes all the mix designs used in this experimental study. As shown, a number of specimens were prepared at various dosages and binder compositions. The dosages presented herein were based on the weight $(\mathrm{w} / \mathrm{w})$ of the amorphous peat at the average water content of $120 \%$. For the comparison purpose, a set of control specimens was prepared (cases 1.1-1.3). Case 1.1 was the raw amorphous peat, which was prepared without any pretreatments and additives. In the other sets (cases 1.2 and $1.3)$, the peat was treated only using reagents $\left(\mathrm{CaCl}_{2} /\right.$ urea/ nutrient broth) without any ureolytic bacteria culture. The SSP dosage varied from 0 to $50 \%$ (refer to cases $2-12$ ). The range of the SSP dosage was reasonably chosen to be similar to the typical dosage of PC used to stabilize peat deposits (Paul and Hussain, 2020). The binder (MICP) dosage varied for three different levels (refer to cases 13-15). In fact, these three levels correspond to 0.5, 1.0 , and $2.0 \mathrm{~mol} / \mathrm{L}$ concentrations of $\mathrm{CaCl}_{2}$ and urea (cases 13,14 , and 15 , respectively), if the bulk volume of the specimen is assumed to be equivalent to the solvent volume. The above range of concentrations were selected based on the previous 


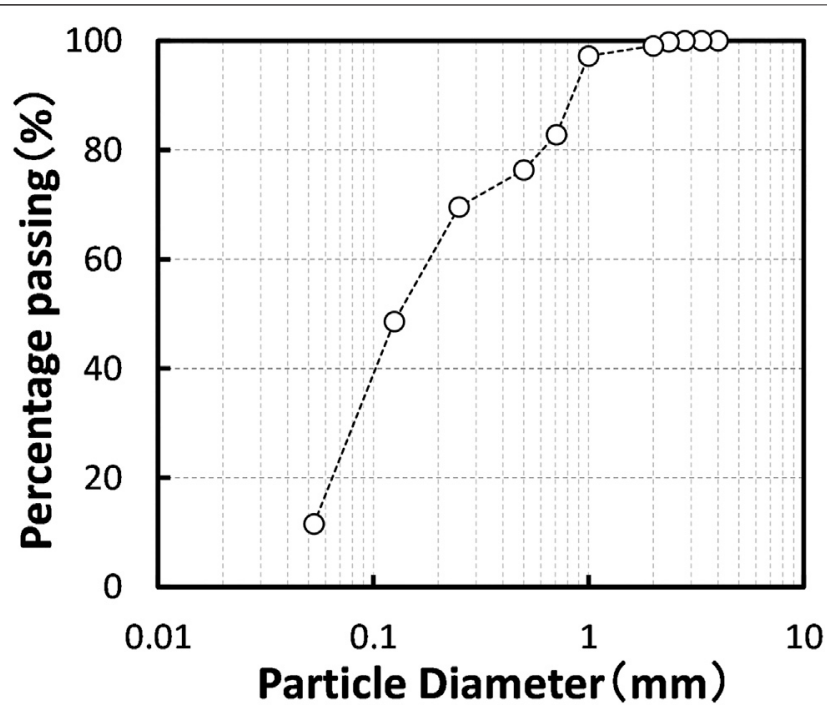

FIGURE 1 | Grain size distribution curve of SSP used in this study.

TABLE 2 | Chemical composition analysis results of SSP.

\begin{tabular}{lcl} 
Compound & Value (\%) & Test/standard \\
\hline $\mathrm{CaO}$ & 54.70 & JIS (1994) \\
$\mathrm{Na}_{2} \mathrm{O}$ & 3.16 & JIS $(1994)$ \\
$\mathrm{MgO}$ & 0.13 & JIS $(1994)$ \\
$\mathrm{P}_{4} \mathrm{O}_{10}$ & 0.05 & JIS $(1994)$ \\
$\mathrm{Fe}_{2} \mathrm{O}_{3}$ & $<0.01$ & JIS $(1994)$ \\
$\mathrm{Al}_{2} \mathrm{O}_{3}$ & $<0.01$ & JIS $(1994)$ \\
$\mathrm{SiO}_{2}$ & $<0.01$ & JIS $(1994)$ \\
$\mathrm{Cu}$ & $<0.01$ & Atomic absorption spectrometry \\
$\mathrm{Pb}_{\mathrm{Cd}}$ & $<0.01$ & Atomic absorption spectrometry \\
$\mathrm{Cd}$ & $<0.01$ & Atomic absorption spectrometry \\
$\mathrm{Ag}$ & $<0.01$ & Atomic absorption spectrometry \\
Total sulfur & 0.12 & JIS, (1994) \\
Ignition loss & 44 & JIS (1994) \\
Ash content & 1.30 & Based on the weight after heating at $550^{\circ} \mathrm{C}$ \\
Moisture content & 0.2 & Based on the weight loss after drying at $105^{\circ} \mathrm{C}$
\end{tabular}

reports (Dhami et al., 2013; Mujah et al., 2017). On the basis of the best mix design developed, cases 16-19 were carried out to assess the effect of curing time. The unconfined compression test, one of the widely used laboratory tests for soil stabilization applications (Kawasaki and Akiyama, 2013), was performed on treated peat specimens (Table 3), and the effects of the factors on their UCS were evaluated. Since this is a pilot-scale study to assess the possible use of SSP in MICP treatment, one specimen was prepared and tested for each case.

\section{Methods of Testing}

After curing, the molds were removed, and specimens were carefully taken out. The UCS of the test specimens was measured using the compression testing machine, T266-31100 (Seikensha Co., Ltd., Japan). During the displacement-controlled test, the specimens were compressed at an axial strain rate of $1 \% / \mathrm{min}$ until the axial strain reached $16 \%$. The test setup used for measuring the UCS is depicted in Figure 3. The $\mathrm{pH}$ was measured using the LAQUA-9615S $\mathrm{pH}$ meter (HORIBA Advanced Co., Ltd., Japan) for the purpose of evaluating the alkalinity of the peat after mixing. Following compression tests, representative samples were taken from the specimens and observed through SEM using Miniscope TM 3000 (Hitachi, Tokyo, Japan) after being oven dried at $60^{\circ} \mathrm{C}$ for $24 \mathrm{~h}$ in order to observe the microstructure of the MICP-treated peat. The EDX analysis was performed to map the chemical distribution of calcium products and silica in the treated peat. To minimize charges occurring from the electron beam and to result in high-quality imaging, the samples were coated with an ultrathin layer of carbon using EC-32010CC(JEOL) (Tokyo, Japan). Moreover, the $\mathrm{XRD}$ analysis was carried out on powdered samples at a scan rate of $6.5^{\circ} \mathrm{min}$ and at angles from $5^{\circ}$ to $70^{\circ}(2 \theta)$ using the diffractometer (MultiFlex-Rigaku, Tokyo, Japan) equipped with an X-ray source.

\section{RESULTS AND DISCUSSION}

\section{pH Regulation of Peat}

Initial $\mathrm{pH}$ of the soil/reaction medium is an important factor that governs the growth of the bacteria, bacterial metabolism and $\mathrm{CaCO}_{3}$ formation (Tang et al., 2020). Based on many previous reports, it is clear that the highest urea decomposition rate of the bacteria ranges between neutral to weak alkaline conditions (Whiffin et al., 2007; Fujita et al., 2017; Gowthaman et al., 2019). Additionally, the neutral alkaline conditions increase the proportion of total carbonate that exists as $\mathrm{CO}_{3}{ }^{2-}$, creating an ideal condition for the formation of $\mathrm{CaCO}_{3}$ (Cheng et al., 2014; Keykha et al., 2017). Because the pH of the peat studied herein was 2.5 , its regulation was the prerequisite for an effective MICP treatment. Therefore, to determine the appropriate dosage of the $\mathrm{pH}$ adjuster, the peat was prepared at varying dosages of $\mathrm{CaO}_{2}$ ( $0-5 \%$ by weight) and was tested for $\mathrm{pH}$ after the mixing process. From the results (Supplementary Figure S2A), it could be seen that the $\mathrm{pH}$ increases with the increase in the $\mathrm{CaO}_{2}$ dosage, suggesting that the dosage could neutralize humic acid in peat. Based on these preliminary results, $1 \%$ dosage of $\mathrm{CaO}_{2}$ was chosen to upsurge the $\mathrm{pH}$ of the peat mix from 2.5 to 5.0. However, the definitive $\mathrm{pH}$ of the mix was determined by the SSP. As shown in Supplementary Figure S2B, the humic substances were further tended to neutralize when the SSP was introduced, thus the $\mathrm{pH}$ of the mix raised above 6.0. It is worth noting that such initial $\mathrm{pH}$ value is well above the required $\mathrm{pH}$ for the MICP-based peat stabilization to be effective as demonstrated by Canakci et al. (2015).

\section{Unconfined Compressive Strength Effect of Scallop Shell Powder on Unconfined Compressive Strength of the Peat}

Figure $4 \mathrm{~A}$ presents the effect of SSP on the stress-strain responses of the MICP-treated peat under compression. In the above cases, the specimens were identically treated (except the SSP dosage) and tested after 7 days of curing. Figure $4 \mathrm{~B}$ compares the UCS values of the treated peat with different control cases. It should be noted that the UCS of the raw peat of Tomikawa (Hokkaido, Japan) was found to be $8.3 \mathrm{kPa}$ (cases 1.1). Meanwhile, the UCS was $16.6 \pm 1.6 \mathrm{kPa}$ for the peat treated using MICP reagents without any bacteria culture (cases 1.2 and 


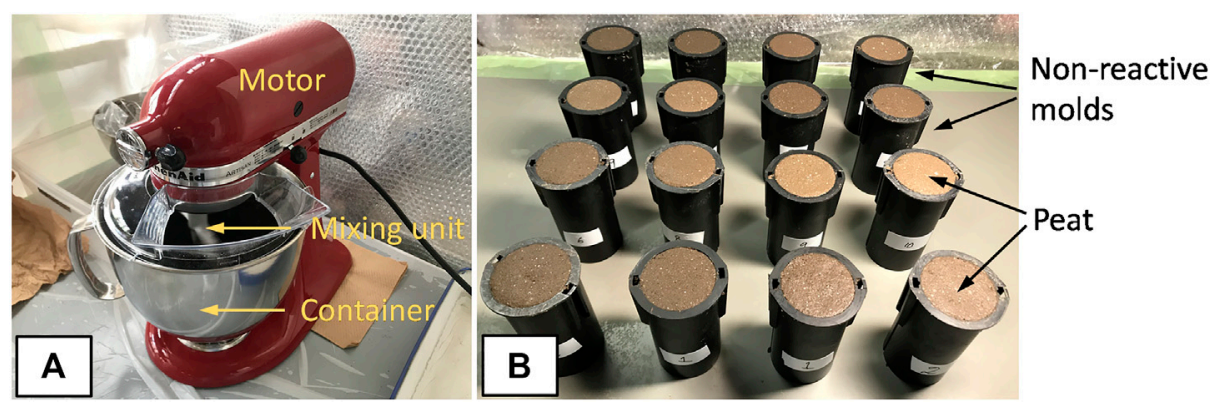

FIGURE 2 | Preparation of amorphous peat specimens: (A) mechanical mixer and (B) specimens placed into nonreactive cylindrical molds of 50 mm in diameter and $100 \mathrm{~mm}$ in height.

TABLE 3 | Mix designs of specimens prepared for unconfined compression tests.

\begin{tabular}{|c|c|c|c|c|c|c|c|c|}
\hline \multirow{2}{*}{$\begin{array}{l}\text { Testing } \\
\text { case }\end{array}$} & \multirow[t]{2}{*}{ Purpose } & \multirow{2}{*}{$\begin{array}{c}\mathrm{CaO}_{2} \\
\text { dosage } \\
(\%)\end{array}$} & \multicolumn{3}{|c|}{ MICP dosage $(\mathrm{g} / \mathrm{kg})$} & \multirow{2}{*}{$\begin{array}{c}\text { SSP } \\
\text { dosage } \\
(\%)\end{array}$} & \multirow{2}{*}{$\begin{array}{l}\text { Bacteria } \\
\text { culture }\end{array}$} & \multirow{2}{*}{$\begin{array}{l}\text { Curing } \\
\text { time } \\
\text { (days) }\end{array}$} \\
\hline & & & $\mathrm{CaCl}_{2}$ & Urea & $\begin{array}{l}\text { Nutrient } \\
\text { broth }\end{array}$ & & & \\
\hline Case 1.1 & \multirow{3}{*}{ Control cases } & - & - & - & - & - & - & 7 \\
\hline Case 1.2 & & 1 & 50.3 & 27.2 & - & - & - & 7 \\
\hline Case 1.3 & & 1 & 50.3 & 27.2 & 3.3 & - & - & 7 \\
\hline Case 2 & \multirow{6}{*}{$\begin{array}{l}\text { To investigate the effects of scallop dosage on MICP } \\
\text { treatment }\end{array}$} & 1 & 50.3 & 27.2 & 3.3 & - & $\sqrt{ }$ & 7 \\
\hline Case 3 & & 1 & 50.3 & 27.2 & 3.3 & 10 & $\sqrt{ }$ & 7 \\
\hline Case 4 & & 1 & 50.3 & 27.2 & 3.3 & 20 & $\sqrt{ }$ & 7 \\
\hline Case 5 & & 1 & 50.3 & 27.2 & 3.3 & 30 & $\sqrt{ }$ & 7 \\
\hline Case 6 & & 1 & 50.3 & 27.2 & 3.3 & 40 & $\sqrt{ }$ & 7 \\
\hline Case 7 & & 1 & 50.3 & 27.2 & 3.3 & 50 & $\sqrt{ }$ & 7 \\
\hline Case 8 & \multirow{5}{*}{$\begin{array}{l}\text { To evaluate the effects of scallop dosage alone (as } \\
\text { control for cases } 3-7 \text { ) }\end{array}$} & - & - & - & - & 10 & - & 7 \\
\hline Case 9 & & - & - & - & - & 20 & - & 7 \\
\hline Case 10 & & - & - & - & - & 30 & - & 7 \\
\hline Case 11 & & - & - & - & - & 40 & - & 7 \\
\hline Case 12 & & - & - & - & - & 50 & - & 7 \\
\hline Case 13 & \multirow{3}{*}{ To investigate the effect of MICP dosage } & 1 & 25.2 & 13.6 & 3.3 & 50 & $\sqrt{ }$ & 7 \\
\hline Case 14 & & 1 & 50.3 & 27.2 & 3.3 & 50 & $\sqrt{ }$ & 7 \\
\hline Case 15 & & 1 & 100.6 & 54.4 & 3.3 & 50 & $\sqrt{ }$ & 7 \\
\hline Case 16 & \multirow{4}{*}{ To investigate the effects of curing duration } & 1 & 50.3 & 27.2 & 3.3 & 50 & $\sqrt{ }$ & 2 \\
\hline Case 17 & & 1 & 50.3 & 27.2 & 3.3 & 50 & $\sqrt{ }$ & 7 \\
\hline Case 18 & & 1 & 50.3 & 27.2 & 3.3 & 50 & $\sqrt{ }$ & 14 \\
\hline Case 19 & & 1 & 50.3 & 27.2 & 3.3 & 50 & $\sqrt{ }$ & 28 \\
\hline
\end{tabular}

1.3), which was used as a reference to compare with the treated peat. When the MICP was solely introduced to the peat (refer to $0 \%$ in Figure 4A), the UCS increased to around $16.2 \mathrm{kPa}$, indicating that MICP alone is not effective for stiffening the skeleton of the peat. However, the UCS was found to be significantly enhanced when the SSP was involved in MICP treatment of peat. The observations (in Figure 4B) suggest that an increase in the UCS was obtained with the increase in the SSP dosage in MICP treatment. Due to the dosage from 10 to $50 \%$ of SSP, the MICP-treated peat experienced an increase in the UCS by around 16-206\%, respectively.

The stress-strain relationships of the peat treated by SSP alone (i.e., in the absence of MICP) are shown in Figure 5A. It is manifested that the UCS increased with an increase the SSP dosage, which is consistent with the tendency observed for MICP + SSP cases (refer to Figure 4A). The overall comparison (presented in Figure 5B), however, suggests that the enhancement imposed by SSP was subordinate (compared with MICP + SSP treatment). For instance, the comparison of UCS corresponding to $50 \%$ of SSP reveals an increase of $140 \%$ when treated by SSP alone, while it was above $200 \%$ when treated by SSP and MICP together (Figure 5B). This 27\% strength difference clearly demonstrate the binding effect of MICP in peat deposits.

A number of previous studies disclosed that the compressibility of peat deposits is governed by many factors, 


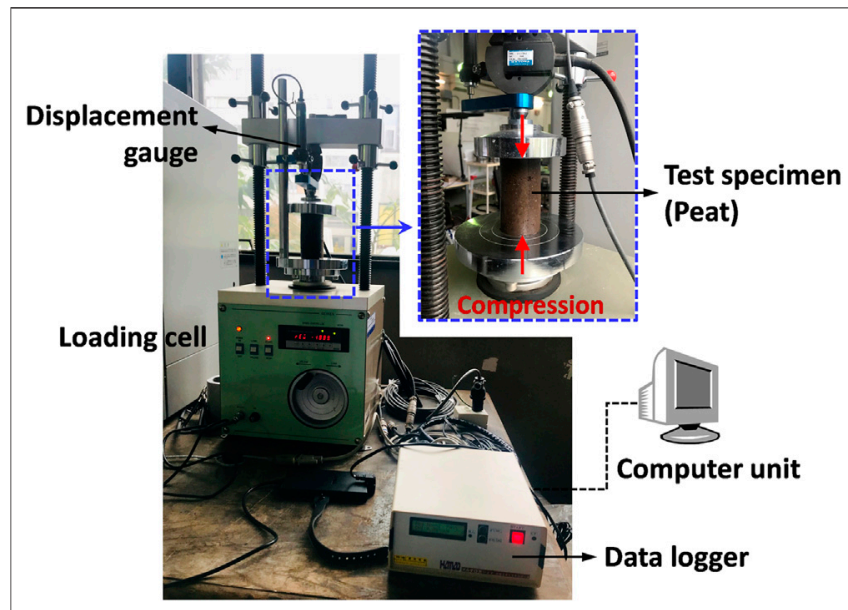

FIGURE 3 | Equipment set up: unconfined compression test.

such as water content, density, characteristics of fibers, degree of decomposition, and existence of inorganic minerals (Zulkifley et al., 2014; O'Kelly, 2017; Paul and Hussain, 2020). Here, the major mechanism for the SSP dosage to enhance the strength of the peat is possibly the densification of the peat. Figure 6 depicts the variation of dry density (determined after the preparation of specimens) against the SSP dosage. The observation reveals that the increase in the SSP dosage decreased the void ratio and increased the dry density of peat, and thus enhanced the resistance against the compression as witnessed in Figure 5. At the same time, the peat specimens gained additional strength when the MICP was implemented together with the SSP dosage (refer to Figure 4). This could be attributed to the formation of calcium carbonate crystals at the particle-particle contact areas as a consequence of urea hydrolysis, which develops structural continuity in the specimen.

At high water content and low density, the solid particles in peat have less interaction with adjacent particles (Chen et al., 2021). As the result, the effective calcium carbonate bonds between adjacent solids were limitedly attainable when the MICP was induced alone. However, the amendment by SSP aided to overcome this contest. As the SSP dosage increased from 0 to $50 \%$, the efficacy of MICP became more pronounced. A similar observation was also reported by Feng and Montoya (2016) that the denser initial soil state leads to higher strength in MICP treatment. Besides, as the MICP is in progress, the water molecules are progressively consumed. For instance, the peat treated by $50 \%$ SSP and MICP showed an initial water content of around $55.0 \%$, yet it was found to be around $48.5 \%$ after 7 -day curing period. It is worthwhile mentioning that the consumption of water during the curing process would contribute to the enhancement in solidity of the peat, which is desirable.

Moreover, the stress-strain curves (Figure 5) show evident changes in the peat's deformation behavior; the SSP addition increased the stiffness and transformed the failure mode of the peat from ductile-like to brittle-like. Figure 7 shows the photographs of the deformed peat specimens of different cases immediately after the compression tests. As expected, the untreated peat (Figure 7A) remained very soft and showed a bulged and discrete failure due to the absence of cohesion between particles. A similar deformation was also witnessed previously by O'Kelly (2015) for the raw amorphous peat. When the MICP was solely implemented, the separation in specimen did not occur during compression (Figure 7B), indicating the increase in cohesive forces between particles. However, the specimen was not stiff enough, hence underwent a plastic compression. The specimens that were treated by SSP alone (Figures 7C,D) exhibited shear failure patterns under compression, which is more likely to be the deformation behavior of inorganic soft clay (Arpajirakul et al., 2021). On the other hand, neither splitting nor apparent local failures were observed in the specimens treated by integrating MICP and SSP (Figures 7E,F). This well-preserved skeleton serves as evidence that the bacteria which had been distributed throughout the specimen could induce MICP cementation between particles during the treatment and enhance the endurance of the SSPpeat mix.

\section{Effect of Binder Dosage on Unconfined Compressive Strength of the Peat}

Figure 8 compares the stress-strain graphs of the specimens treated using different initial binder compositions, that is, the concentrations of MICP resources in a range from 0.5 to $2.0 \mathrm{~mol} /$ L. As mentioned earlier, UCS of control specimen was $16.6 \mathrm{kPa}$. It is evident from Figure $\mathbf{8}$ that the specimen with a binder concentration of $1 \mathrm{~mol} / \mathrm{L}$ had an optimal UCS of around $50 \mathrm{kPa}$ by the end of 7 days of curing. The specimens treated by $2 \mathrm{~mol} / \mathrm{L}$ exhibited a weakening behavior; the measured UCS was less than even the UCS of the raw peat. It was anticipated that the increase in the initial dosage of the binder would improve the strengthening of peat, but instead, higher initial concentrations exhibited a contrary effect on the stiffening of peat specimens, which is in consistent with the literature (Chen et al., 2021). This discrepancy can be explained by several factors such as enzyme denaturation and inhibition of urease activity. Urea is a wellknown chaotropic agent, which destabilize the protein at their high concentrations (Cabrita and Bottomley, 2004; Yamaguchi and Miyazaki, 2014). During the treatment by $2 \mathrm{~mol} / \mathrm{L}$ concentrated urea (cases 15), the hydrophobic interactions in protein molecules were possibly disrupted, resulting in reduced functionality of bacteria. Perhaps, as Safdar et al. (2021) indicated, higher calcium chloride concentrations (e.g., $2 \mathrm{~mol} / \mathrm{L}$ ) also might inhibit the urea hydrolysis. Here, the finding demonstrates that for an effective stabilization of the peat soil, the concentration of MICP resources needs to be determined appropriately.

\section{Effect of Curing Period on the Unconfined Compressive Strength of the Peat}

Figure 9A illustrates the variation of UCS with different curing periods (after 2, 7, 14, and 28 days). As shown, the UCS increases with the increase in curing period. For example, by the end of 2 day curing period, the UCS remained to be around $20 \mathrm{kPa}$, and increased over $100 \mathrm{kPa}$ by the end of 28-day curing period. In the MICP treatment, the strengthening of peat tends to occur due to the formation of $\mathrm{CaCO}_{3}$ which could reduce the void spaces and 

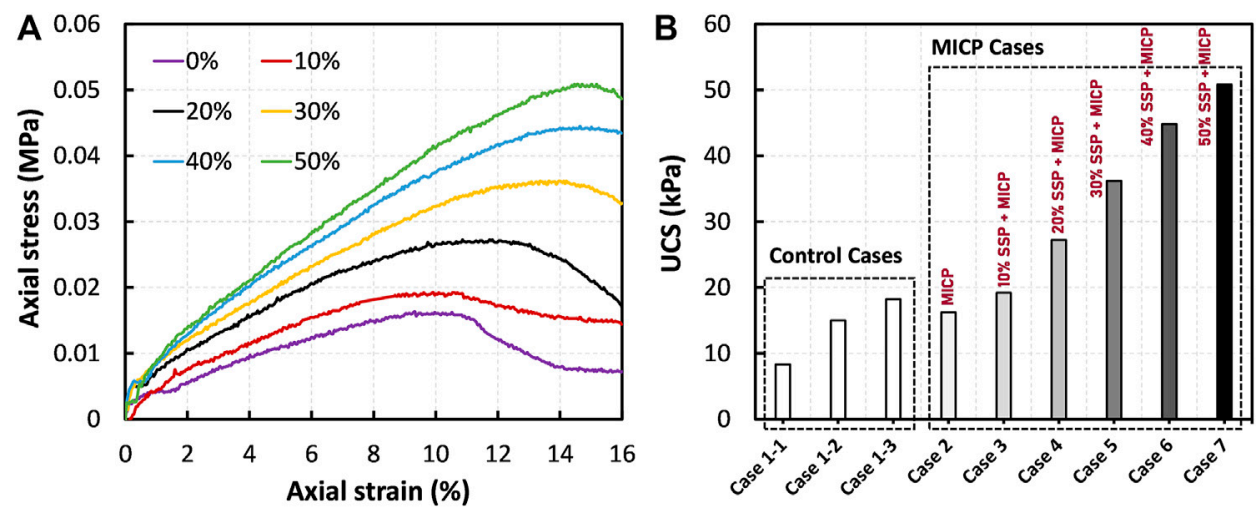

FIGURE 4 | (A) Effect of SSP on the stress-strain responses of the MICP-treated peat under compression: comparison between the cases 2-7, and (B) comparison of UCS together with control cases.
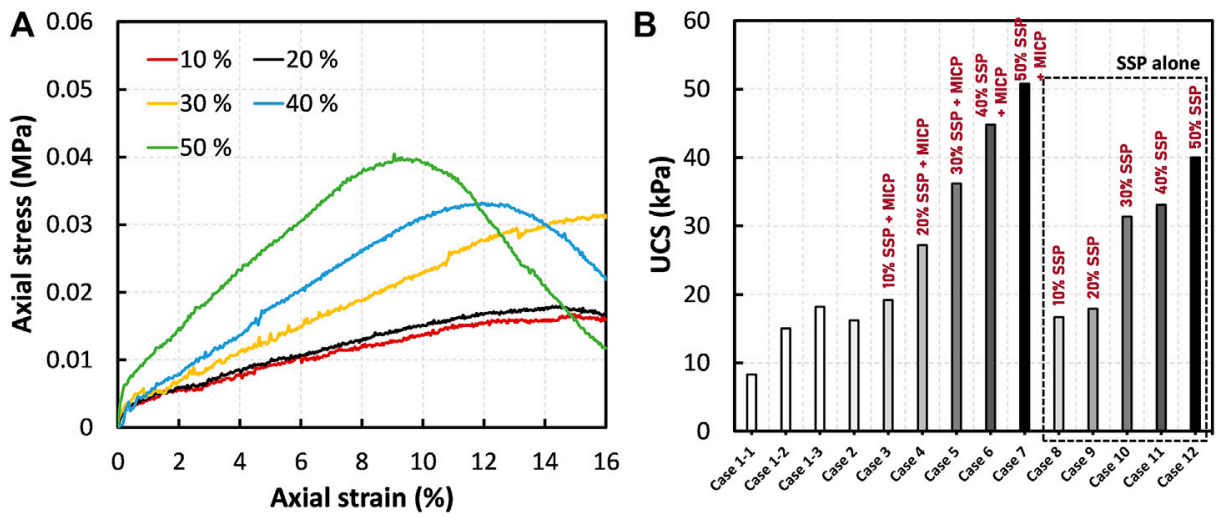

FIGURE $\mathbf{5}$ | (A) Effect of SSP on the stress-strain responses of peat (without MICP): comparison between the cases 8-12, and (B) comparison of UCS with both MICP and control cases.

cement the organic as well as SSP particles. As the precipitation content of calcium carbonate increased with the increasing curing time, the peat specimens became gradually stiffer.

The quantification of precipitated $\mathrm{CaCO}_{3}$ is often an important part in MICP-related soil improvement studies. Most of the researchers evaluated the amount of $\mathrm{CaCO}_{3}$ by the acid-washing method; two approaches are widespread: (i) measuring the difference between dry mass of soil before and after dissolving $\mathrm{CaCO}_{3}$ (Neupane et al., 2015) and (ii) measuring the pressure of $\mathrm{CO}_{2}$ gas released during the reaction of $\mathrm{CaCO}_{3}$ with $\mathrm{HCl}$ (Fukue et al., 2011; Gowthaman et al., 2021a). However, the acid-washing methods are less applicable to the soils that already consist of carbonates in their mineralogy. Since the component of SSP is $\mathrm{CaCO}_{3}$, the determination of precipitated $\mathrm{CaCO}_{3}$ by acidwashing herein was greatly challenging. Alternatively, $\mathrm{Ca}^{2+}$ ions existed in peat before and after curing was quantitatively evaluated, and the difference was considered as the contributor to the crystallization. Figure 9B illustrates the estimated $\mathrm{CaCO}_{3}$ contents after 7 and 28 days of curing, together with the theoretical maximum. The measurements indicated that the precipitation content, by the end of 28-day curing period, was around $3.6 \%$ (i.e., $0.036 \mathrm{~g} / \mathrm{g}$ peat), which is 1.5 -fold higher compared to that precipitated after 7-day curing period. It is important to note that the precipitation content achieved in 28 days was around $55 \%$ of the theoretical maximum that could have been precipitated $(\sim 6.5 \%$ by weight $)$. The difference in conversion could possibly be attributed to the denaturation of microbial urease. Many previous studies found that the activity of the bacteria begins to decrease after 1-2 weeks, which is conceivably due to the following reasons: nutrient deficiency, oxygen shortage, and proteolysis (Whiffin 2004; Gowthaman et al., 2019). As the result of incomplete urea hydrolysis, the achieved content of $\mathrm{CaCO}_{3}$ (3.6\%) was quite lower than the maximum possible value $(6.5 \%)$. Nevertheless, it is verified that the UCS gain is generally higher for the higher precipitation content.

\section{Characterization of Microstructure}

SEM images depicted in Figure 10 illustrate the morphology of both untreated and treated amorphous peat. The raw peat, shown 


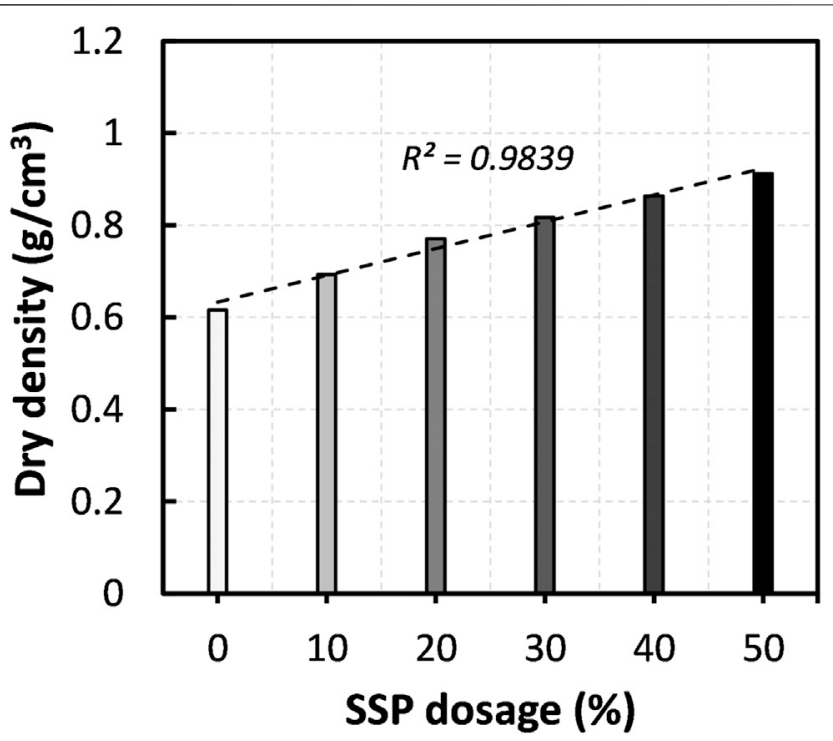

FIGURE 6 | The variation of dry density of the specimens with the increase in the SSP dosage.

in Figure 10A, revealed a complex texture, and the components were difficult to be distinguished by observation. The absence of visible plant remains/debris in the aggregation further indicated high degree of decomposition of the amorphous peat. In the MICP-treated peat, a layer of irregular-shaped crystals was evident on and around the surfaces (Figure 10B). The crystals were small and were more likely to be having a rhombohedral shape. However, these MICP cementations at the connection points of organic particles insignificantly enhanced the UCS of the treated matrix. As highlighted by Canakci et al. (2015), the failure of the organic matrix tends to occur through weak organic particles rather the calcium carbonate bonds, when the stress is imposed. Therefore, poor improvement was obtained in peat even after treatment.

The distribution of SSP in peat is shown in Figure 10C, revealing that the mixed plate-like SSP particles (in a range between $0.1-1 \mathrm{~mm}$ ) were disseminated throughout the peat. However, the SSP addition alone was also unlikely to result in a stiff skeleton of peat, that is, the achieved UCS was less than $40 \mathrm{kPa}$ corresponding to the $50 \%$ SSP dosage, which is still below the typical threshold of $50 \mathrm{kPa}$. This could mainly be attributed to the absence of binding effect. Additionally, in most of the places, huge spacings between SSP particles were observed, indicating poor development of calcium carbonate force chain. At the same time, when the MICP was integrated together with SSP, the skeleton appeared to be improved as expected (Figure 10D). The rhombohedral crystals were again clearly observed, which formed bridges not only between soil particles, but also between SSP and soil particles, and eventually resulted in stronger soil with the UCS over $50 \mathrm{kPa}$.

In fact, the term "connectivity" would be more appropriate herein to discuss the strengthening of the peat. For the peat, to get a sufficient compressive strength, the resistivity of the skeleton needs to be improved (Wong et al., 2013). In the case of PC, the formation of porous cement gel (consisting calcium silica hydrates, ettringite, and hydrated lime) continues to grow through the pore spaces and develops the connectivity of the peat soil, thus enhancing its overall resistance to compression (Zulkifley et al., 2014). Here, although the calcium carbonate crystals are formed around and/or between peat particles, the overall connectivity achieved in skeleton is very limited, which is also in consistent with the case treated with SSP alone. The above concept was corroborated well by mapping the distribution of calcium in peat (based on the EDX analysis), which is a proxy of calcium carbonate (refer to Figure 11). The detection in Peat + MICP + SSP combined case revealed a significant increase in overall connectivity of stiff calcium carbonate (the calcium has been detected in yellow color) though the organic and silica matrix (silica has been detected in red color) (Figure 11). The plots of intensity against energy can be found in Supplementary Figure S3. Particularly, the large-sized SSP was more likely to be connected by MICP crystallization. As the result of this chain development, the specimens were able to resist high compressive forces and revealed less deformation. It is worth mentioning that the authors believe that further increase in the SSP content in treatment will result in higher UCS and that may be comparable to traditional treatments.

The XRD analysis confirmed that the main minerals that existed in the raw peat and SSP were quartz and calcite,

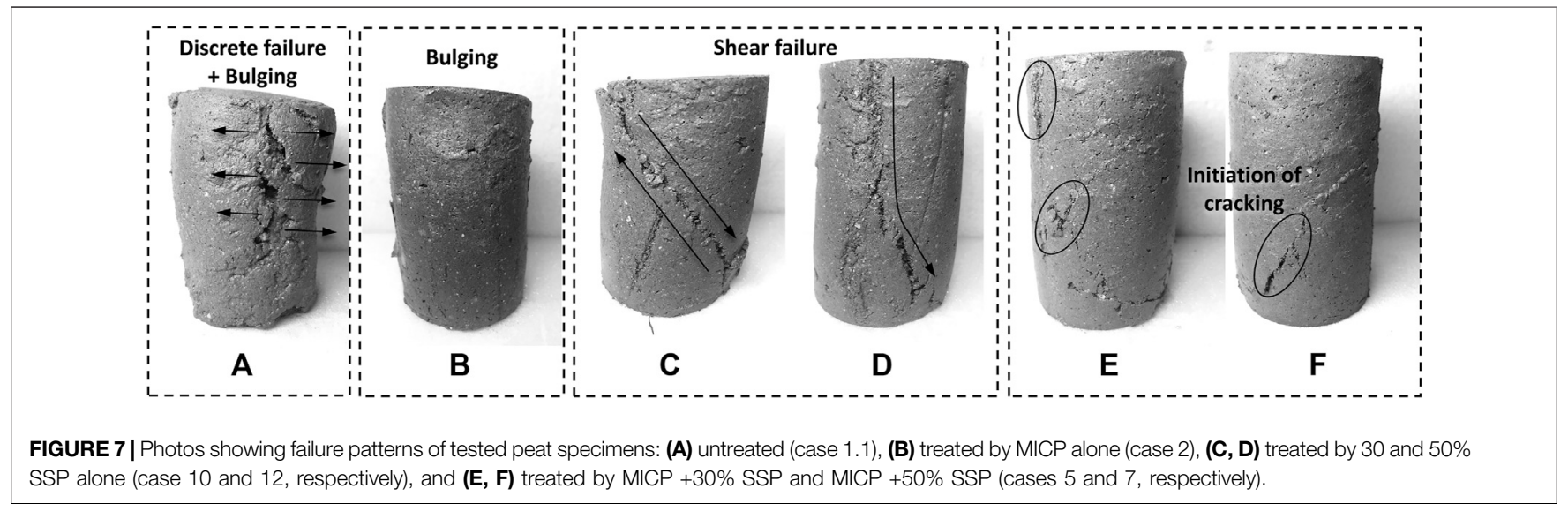




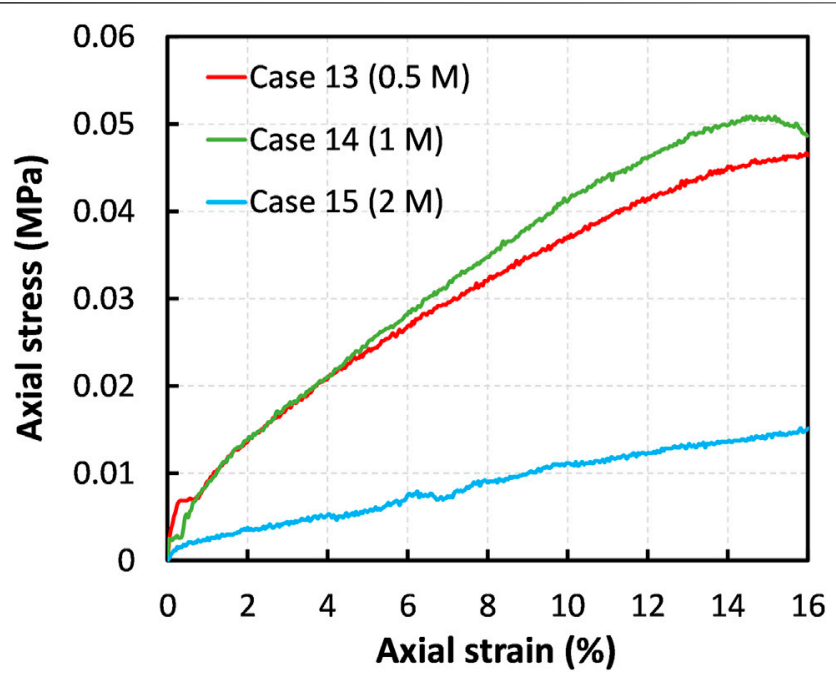

FIGURE 8 | Effect of the MICP binder dosage on strengthening of the treated amorphous peat: comparison between the cases 13-15.

respectively (refer to Figures 12A,B). In fact, the presence of quartz is very common in peat deposits depending on the surrounding geology of peatlands, and previous studies also witnessed the quartz in peat soils (Paul and Hussain, 2020). From Figures 12C,D, it could be seen that the polymorph of calcium carbonate that mineralized during MICP was calcite. It should be noted that even though the precipitation type was calcite, typical larger clusters were not detected in the SEM analysis; but instead, an unidentifiable and smaller microstructure was captured (Figure 12C). This might be attributed to the effect of organic matter that inhibited the growth of crystals. Several previous studies reported that the organic matter content partially exhaust the supplied $\mathrm{Ca}^{2+}$ ions, inhibiting the cementation reactions (Venda Oliveira and Neves, 2019; Chung et al., 2020). Nevertheless, precipitated calcite is the responsible material which helps in binding the organic matters and SSP together.
Urease producing bacteria are found in abundance in soils (Mitchell and Santamarina, 2005). However, the MICP process (i.e., urea hydrolysis) releases ammonium by-products which are undesirable to geo-environment (Mohsenzadeh et al., 2021). Contamination of ammonium ions would acidify the ground water and/or water bodies, which eventually affects plant and animal life. In particular, high aqueous ammonia in surface water enhances the blooms of toxic algae, depletes the dissolved oxygen, and results in aquatic toxicity which is harmful to aquatic microflora (Keykha et al., 2019). Therefore, for a successful engineering application, facilities/methods for the removal of ammonium by-products from the MICP-treated strata are required, which would probably be a challenging process at the industrial scale.

The feasibility of the proposed method for industrial-scale applications requires a thorough assessment from different perspectives. In general, nondestructive methods are convincing best practices and are preferable in geotechnical engineering. Amorphous peatlands, however, are likely to be a challenge in supplying the bacteria and reagents, because of their less open pore structure and hydraulic conductivity. In situ mixing can therefore be the most suitable way to implement. Similar to that demonstrated in pilot scale, the bacteria, reagents, and nutrients can be introduced to peatlands using mechanical mixers that had been typically used to mix PC. Considering the challenges, viability of the bacterial cells under the stresses associated with industrial mixing was the major concern. However, a recent work has verified the feasibility of using gram-positive bacteria (e.g., Sporosarcina sp.) which have thick cell walls to potentially protect from puncture/lysis under industrial mixing process (Duraisamy, 2016). It should be mentioned that under existing infrastructure, the proposed mixing may be less feasible. The longevity of the $\mathrm{CaCO}_{3}$ under acidic environment of the peat is another frequently raised concern (Gowthaman et al., 2021b). However, the $\mathrm{pH}$ adjustment performed in early stage of the treatment (using $\mathrm{CaO}_{2}$ ) could result in favor, ensuring its longevity and persistence.
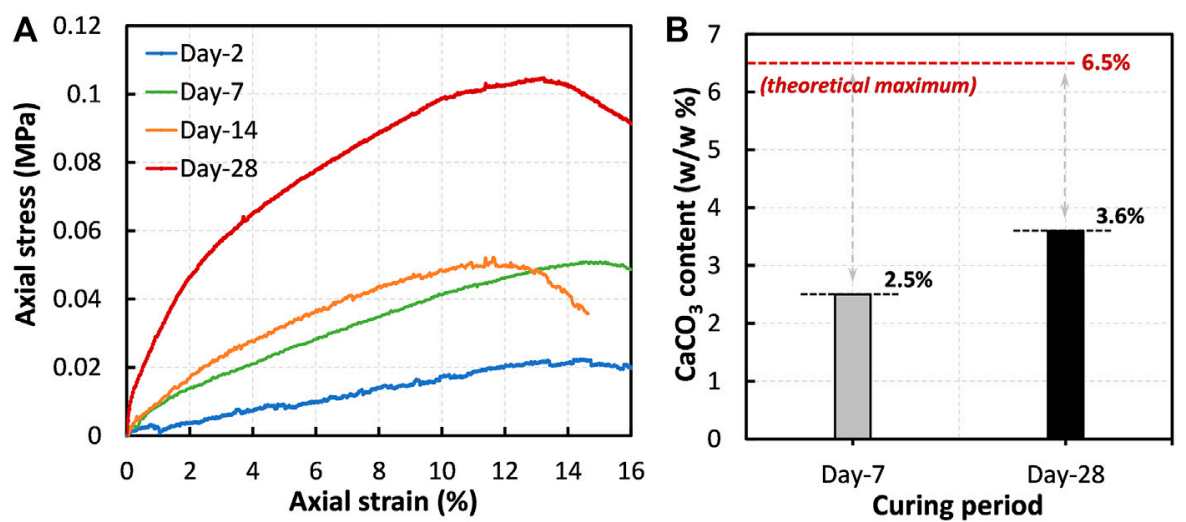

FIGURE 9 | (A) Effect of curing duration on strengthening of the treated amorphous peat: comparison between the cases 16-19 and (B) comparison of the precipitated $\mathrm{CaCO}_{3}$ content. 

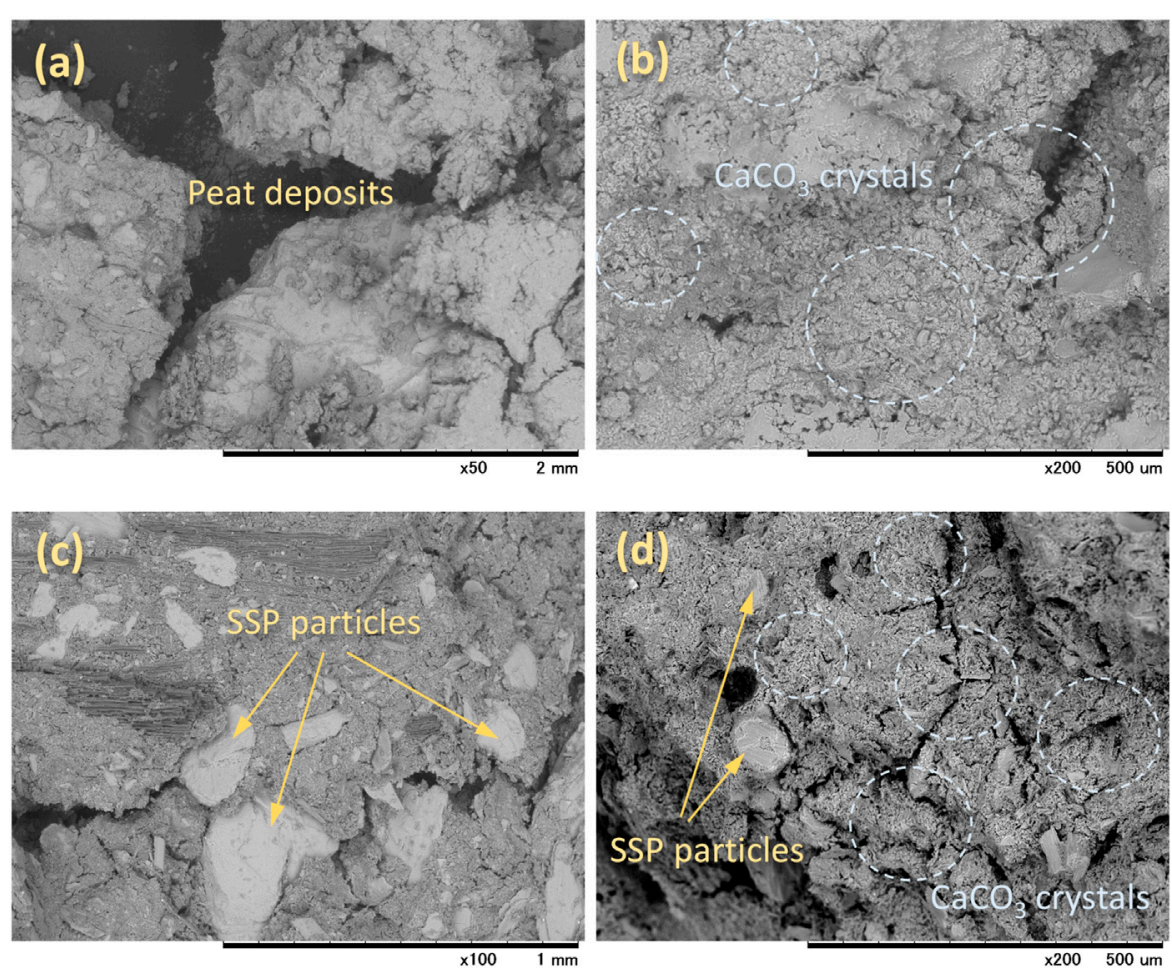

FIGURE 10 | Micrographs of the (A) untreated peat, (B) peat treated by MICP alone, (C) peat treated by SSP alone, and (D) peat treated by MICP + SSP.

SEM Silica
Peat + SSP
Peat + SSP
+ MICP




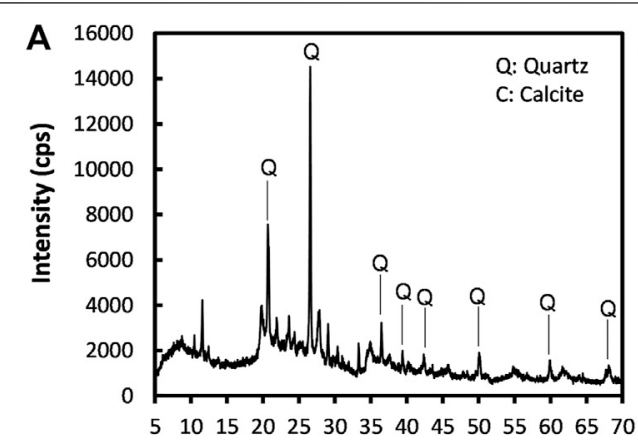

$2 \theta$

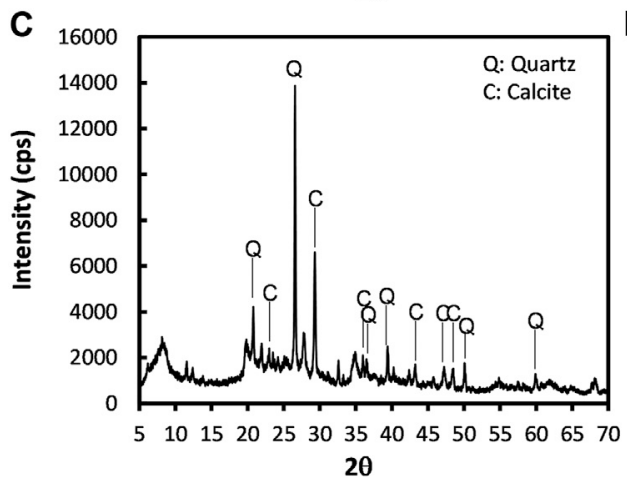

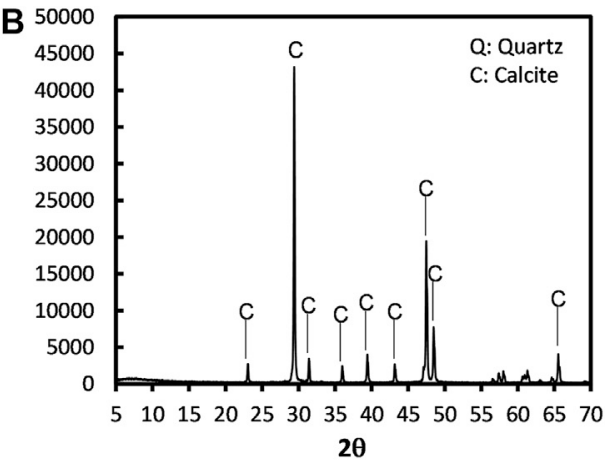

$D_{2}$

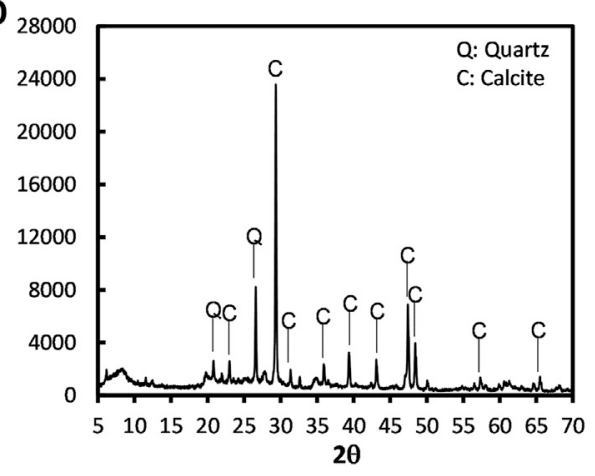

FIGURE 12 | Representative XRD analysis of the mineralogical characterization of the (A) raw peat, (B) SSP, (C) MICP-treated amorphous peat, and (D) MICP + SSP treated amorphous peat.

\section{CONCLUSION}

MICP is one of the emerging soil improvement techniques which has recently drawn a substantial attention for stabilizing variety of soils. The work presented in this study was designed to assess the viability of involving SSP on enhancing the mechanical behavior of the MICP-treated amorphous peat. The evaluation program relied mainly on unconfined compression tests, SEM, EDX analysis, and XRD analysis, and the following conclusions could be drawn based on the study outcomes.

The use of $\mathrm{CaO}_{2}$ (fertilizer product) showed a high potential for $\mathrm{pH}$ regulation of acidic amorphous peat. The outcomes indicated that $1 \%$ (by weight) could raise the $\mathrm{pH}$ of the peat to provide desirable environment for urea hydrolysis. It was evident that the conventional MICP approach resulted in the formation of calcium carbonate crystals, led to the cementation between organic particles. However, the increase in UCS was not significant. The proposed approach, with the inclusion of SSP, was shown to enhance the UCS above the threshold UCS required for the transportation of dump trucks over the peatland. The enhancement could be attributed to the increase in density as well as the development of firm connectivity throughout the treated peat. The outcomes further indicated that the UCS increases with the increase in the SSP content and increasing curing period, while the optimum concentration of MICP resources for the treatment was found to be $1 \mathrm{~mol} / \mathrm{L}$. For instance, the UCS of the peat treated by $50 \%$ SSP and $1 \mathrm{~mol} / \mathrm{L}$ MICP revealed the UCS over $100 \mathrm{kPa}$ after 28 days of curing time, which was around 6.5 times higher than that of the untreated peat. The authors believe that the increase in number of mixing cycles will result in further increase in UCS, and which is left for the future scope. SEM and EDS analyses demonstrated that the presence of SSP and mineralized calcium carbonate inside the peat supported the principle strengthening mechanism, that is, enhancing the connectivity of carbonate throughout the peat. As the result, the skeleton became resistive to compression, and the failure mode of the specimen transitioned from bulging/discrete-like failure to shear failure. The XRD analysis confirmed that the polymorph of calcium carbonate that formed was calcite.

\section{DATA AVAILABILITY STATEMENT}

The raw data supporting the conclusions of this article will be made available by the authors, without undue reservation.

\section{AUTHOR CONTRIBUTIONS}

All the authors listed have made direct and intellectual contribution to the presented work. Particularly, SG designed 
the study, conducted laboratory experiments, and wrote the manuscript; MC performed the laboratory experiments and analyzed the testing results; $\mathrm{KN}$ supported in data interpretations and reviewed the manuscript; SK contributed primary supervision and reviewed and approved it for publication.

\section{FUNDING}

This work was partly supported by the Japanese Society for the Promotion of Science (JSPS) KAKENHI (grant number 19H02229).

\section{REFERENCES}

Achal, V., and Kawasaki, S. (2016). Biogrout: A Novel Binding Material for Soil Improvement and concrete Repair. Front. Microbiol. 7. 112. doi:10.3389/ fmicb.2016.00314

Aiken, T. A., Kwasny, J., and Sha, W. (2020). Resistance of Fly Ash Geopolymer Binders to Organic Acids. Mater. Struct. 53, 115. doi:10.1617/s11527-02001549-x

Arpajirakul, S., Pungrasmi, W., and Likitlersuang, S. (2021). Efficiency of Microbially-Induced Calcite Precipitation in Natural Clays for Ground Improvement. Construction Building Mater. 282, 122722. doi:10.1016/ j.conbuildmat.2021.122722

Benhelal, E., Zahedi, G., and Hashim, H. (2012). A Novel Design for green and Economical Cement Manufacturing. J. Clean. Prod. 22, 60-66. doi:10.1016/ j.jclepro.2011.09.019

Cabrita, L. D., and Bottomley, S. P. (2004). "Protein Expression and Refolding - A Practical Guide to Getting the Most Out of Inclusion Bodies," in Biotechnology Annual Review. Editor M. R. El-Gewely (Amsterdam: Elsevier), 31-50. doi:10.1016/s1387-2656(04)10002-1

Canakci, H., Sidik, W., and Halil Kilic, I. (2015). Effect of Bacterial Calcium Carbonate Precipitation on Compressibility and Shear Strength of Organic Soil. Soils and Foundations 55, 1211-1221. doi:10.1016/j.sandf.2015.09.020

Chen, M., Gowthaman, S., Nakashima, K., and Kawasaki, S. (2021). Evaluating Mechanical Strength of Peat Soil Treated by Fiber Incorporated BioCementation. Geomate 20, 121-127. doi:10.21660/2021.78.Gx162

Cheng, L., and Cord-Ruwisch, R. (2014). Upscaling Effects of Soil Improvement by Microbially Induced Calcite Precipitation by Surface Percolation. Geomicrobiology J. 31, 396-406. doi:10.1080/01490451.2013.836579

Cheng, L., Shahin, M. A., and Cord-Ruwisch, R. (2014). Bio-cementation of sandy Soil Using Microbially Induced Carbonate Precipitation for marine Environments. Géotechnique 64, 1010-1013. doi:10.1680/geot.14.T.025

Chung, H., Kim, S. H., and Nam, K. (2020). Application of Microbially Induced Calcite Precipitation to Prevent Soil Loss by Rainfall: Effect of Particle Size and Organic Matter Content. Journal of Soils and Sediments 11, 114. doi:10.1007/s11368-020-02757-2

DeJong, J. T., Mortensen, B. M., Martinez, B. C., and Nelson, D. C. (2010). Biomediated Soil Improvement. Ecol. Eng. 36, 197-210. doi:10.1016/ j.ecoleng.2008.12.029

Dhami, N. K., Reddy, M. S., and Mukherjee, A. (2013). Biomineralization of Calcium Carbonates and Their Engineered Applications: A Review. Front. Microbiol. 4, 1-13. doi:10.3389/fmicb.2013.00314

Duraisamy, Y. (2016). Strength and Stiffness Improvement of Bio-Cemented Sydney Sand. PhD Dissertation. Sydney: University of Sydney.

Feng, K., and Montoya, B. M. (2016). Influence of Confinement and Cementation Level on the Behavior of Microbial-Induced Calcite Precipitated Sands under Monotonic Drained Loading. J. Geotechnical Geoenvironmental Eng. 142, 04015057. doi:10.1061/(ASCE)GT.1943-5606.0001379

Fujita, M., Nakashima, K., Achal, V., and Kawasaki, S. (2017). Whole-cell Evaluation of Urease Activity of Pararhodobacter Sp. Isolated from Peripheral Beachrock. Biochem. Eng. J. 124, 1-5. doi:10.1016/j.bej.2017.04.004

\section{ACKNOWLEDGMENTS}

The authors would like to thank the Civil Engineering Research Institute for Cold Region (Sapporo, Japan) for their support, particularly during the field work, sampling process, and experimentation. In addition, this study was partly supported by JSPS KAKENHI (grant number 19H02229).

\section{SUPPLEMENTARY MATERIAL}

The Supplementary Material for this article can be found online at: https://www.frontiersin.org/articles/10.3389/fenvs.2021.690376/ full\#supplementary-material

Fukue, M., Ono, S.-I., and Sato, Y. (2011). Cementation of Sands Due to Microbiologically-Induced Carbonate Precipitation. Soils and Foundations 51, 83-93. doi:10.3208/sandf.51.83

Gowthaman, S., Iki, T., Nakashima, K., Ebina, K., and Kawasaki, S. (2019). Feasibility Study for Slope Soil Stabilization by Microbial Induced Carbonate Precipitation (MICP) Using Indigenous Bacteria Isolated from Cold Subarctic Region. SN Appl. Sci. 1, 1480. doi:10.1007/s42452-019-1508-y

Gowthaman, S., Nakashima, K., and Kawasaki, S. (2021b). Durability Analysis of Bio-Cemented Slope Soil under the Exposure of Acid Rain. J. Soils Sediments 12, 14. doi:10.1007/s11368-021-02997-w

Gowthaman, S., Nakashima, K., and Kawasaki, S. (2021a). Effect of Wetting and Drying Cycles on the Durability of Bio-Cemented Soil of Expressway Slope. Int. J. Environ. Sci. Technol. 139, 105-116. doi:10.1007/s13762-021-03306-1

Gowthaman, S., Nakashima, K., and Kawasaki, S. (2020). Freeze-thaw Durability and Shear Responses of Cemented Slope Soil Treated by Microbial Induced Carbonate Precipitation. Soils and Foundations 60, 840-855. doi:10.1016/ j.sandf.2020.05.012

Hayashi, H., Nishimoto, S., and Takahashi, M. (2011). Field Performance of PVD Combined with Reinforced Embankment on Peaty Ground. Soils and Foundations 51, 191-201. doi:10.3208/sandf.51.191

Hebib, S., and Farrell, E. R. (2003). Some Experiences on the Stabilization of Irish Peats. Can. Geotech. J. 40, 107-120. doi:10.1139/t02-091

Huat, B. B. K., Arun, P., Asadi, A., and Sina, K. (2014). Geotechnics of Organic Soils and Peat. Boca Raton: CRC Press. doi:10.1201/b15627

Huat, B. B. K. (2004). Organic and Peat Soils Engineering. Serdang, Malaysia: University Putra Malaysia Press.

Islam, M. T., Chittoori, B. C. S., and Burbank, M. (2020). Evaluating the Applicability of Biostimulated Calcium Carbonate Precipitation to Stabilize Clayey Soils. J. Mater. Civil Eng. 32, 1-11. doi:10.1061/(ASCE)MT.19435533.0003036

Ivanov, V., Stabnikov, V., Stabnikova, O., and Kawasaki, S. (2019). Environmental Safety and Biosafety in Construction Biotechnology. World J. Microbiol. Biotechnol. 35, 26. doi:10.1007/s11274-019-2598-9

JIS (1994). Methods for Chemical Analysis of Limestone (JIS M 8850). Sappora: Japanese Standards Association.

Kalantari, B. (2010). Stabilization of Tropical Fibrous Peat Using Ordinary Portland Cement and Additives. Boca Raton: CRC Press.

Kawasaki, S., and Akiyama, M. (2013). Enhancement of Unconfined Compressive Strength of Sand Test Pieces Cemented with Calcium Phosphate Compound by Addition of Various Powders. Soils and Foundations 53, 966-976. doi:10.1016/ j.sandf.2013.10.013

Keykha, H. A., Huat, B. B. K., Asadi, A., and Kawasaki, S. (2012). Electrobiogrouting and its Challenges. Int. J. Electrochem. Sci. 7, 1196-1204. doi:10.1680/envgeo.13.00068

Keykha, H. A., Asadi, A., and Zareian, M. (2017). Environmental Factors Affecting the Compressive Strength of Microbiologically Induced Calcite Precipitation-Treated Soil. Geomicrobiology J. 34, 889-894. doi:10.1080/01490451.2017.1291772

Keykha, H. A., Mohamadzadeh, H., Asadi, A., and Kawasaki, S. (2019). Ammonium-Free Carbonate-Producing Bacteria as an Ecofriendly Soil Biostabilizer. Geotech. Test. J. 42, 20170353. doi:10.1520/GTJ20170353 
Lin, H., Suleiman, M. T., Brown, D. G., and Kavazanjian, E. (2016). Mechanical Behavior of Sands Treated by Microbially Induced Carbonate Precipitation. J. Geotechnical Geoenvironmental Eng. 142, 1-13. doi:10.1061/(ASCE) GT.1943-5606.0001383

Mesri, G., and Ajlouni, M. (2007). Engineering Properties of Fibrous Peats. J. Geotech. Geoenviron. Eng. 133, 850-866. doi:10.1061/(asce)10900241(2007)133:7(850)

Mitchell, J. K., and Santamarina, J. C. (2005). Biological Considerations in Geotechnical Engineering. J. Geotech. Geoenviron. Eng. 131, 1222-1233. doi:10.1061/(asce)1090-0241(2005)131:10(1222)

Mohsenzadeh, A., Aflaki, E., Gowthaman, S., Nakashima, K., Kawasaki, S., and Ebadi, T. (2021). A Two-Stage Treatment Process for the Management of Produced Ammonium By-Products in Ureolytic Bio-Cementation Process. Int. J. Environ. Sci. Technol. 2021, 112. doi:10.1007/s13762-021-03138-z

Mujah, D., Shahin, M. A., and Cheng, L. (2017). State-of-the-Art Review of Biocementation by Microbially Induced Calcite Precipitation (MICP) for Soil Stabilization. Geomicrobiology J. 34, 524-537. doi:10.1080/ 01490451.2016.1225866

Neupane, D., Yasuhara, H., Kinoshita, N., and Ando, Y. (2015). Distribution of Mineralized Carbonate and its Quantification Method in Enzyme Mediated Calcite Precipitation Technique. Soils and Foundations 55, 447-457. doi:10.1016/j.sandf.2015.02.018

Noto, S. (1991). Peat Engineering Handbook. Hokkaido, Japan: Civil Engineering Research Institute, Hokkaido Development Bureau.

O’Kelly, B. C. (2015). Effective Stress Strength Testing of Peat. Environ. Geotechnics 2, 33-44. doi:10.1680/envgeo.13.00112

O'Kelly, B. C. (2017). Measurement, Interpretation and Recommended Use of Laboratory Strength Properties of Fibrous Peat. Geotechnical Res. 4, 136-171. doi:10.5194/se-2016-164-rc1

Omoregie, A. I., Palombo, E. A., and Nissom, P. M. (2020). Bioprecipitation of Calcium Carbonate Mediated by Ureolysis: A Review. Environ. Eng. Res. 26, 200379. doi:10.4491/eer.2020.379

Paul, A., and Hussain, M. (2020). Cement Stabilization of Indian Peat: An Experimental Investigation. J. Mater. Civil Eng. 32, 04020350. doi:10.1061/ (ASCE)MT.1943-5533.0003363

Rowe, R. K., and Taechakumthorn, C. (2008). Combined Effect of PVDs and Reinforcement on Embankments over Rate-Sensitive Soils. Geotextiles and Geomembranes 26, 239-249. doi:10.1016/j.geotexmem.2007.10.001

Safdar, M. U., Mavroulidou, M., Gunn, M. J., Garelick, J., Payne, I., and Purchase, D. (2021). Innovative Methods of Ground Improvement for Railway Embankment Peat Fens Foundation Soil. Géotechnique 2020, 1-14. doi:10.1680/jgeot.19.sip.030

Sato, A., Kawasaki, S., Hata, T., and Hayashi, T. (2016). Possibility for Solidification of Peaty Soil by Using Microbes. Geomate 10, 2071-2076. doi:10.21660/ 2016.22.5353
Sharma, M., Satyam, N., and Reddy, K. R. (2021). Effect of Freeze-Thaw Cycles on Engineering Properties of Biocemented Sand under Different Treatment Conditions. Eng. Geology. 284, 106022. doi:10.1016/j.enggeo.2021.106022

Tang, C.-S., Yin, L.-y., Jiang, N.-j., Zhu, C., Zeng, H., Li, H., et al. (2020). Factors Affecting the Performance of Microbial-Induced Carbonate Precipitation (MICP) Treated Soil: a Review. Environ. Earth Sci. 79, 94. doi:10.1007/s12665-020-8840-9 van Paassen, L. A., Ghose, R., van der Linden, T. J. M., van der Star, W. R. L., and van Loosdrecht, M. C. M. (2010). Quantifying Biomediated Ground Improvement by Ureolysis: Large-Scale Biogrout Experiment. J. Geotech. Geoenviron. Eng. 136, 1721-1728. doi:10.1061/(ASCE)GT.1943-5606.0000382

Venda Oliveira, P. J., and Neves, J. P. G. (2019). Effect of Organic Matter Content on Enzymatic Biocementation Process Applied to Coarse-Grained Soils. J. Mater. Civil Eng. 31, 1-11. doi:10.1061/(ASCE)MT.1943-5533.0002774

Whiffin, V. S. (2004). Microbial $\mathrm{CaCO}_{3}$ Precipitation for the Production of Biocement. Western Australia: PhD Dissertation Murdoch University.

Whiffin, V. S., van Paassen, L. A., and Harkes, M. P. (2007). Microbial Carbonate Precipitation as a Soil Improvement Technique. Geomicrobiology J. 24, 417-423. doi:10.1080/01490450701436505

Wong, L. S., Hashim, R., and Ali, F. (2013). Improved Strength and Reduced Permeability of Stabilized Peat: Focus on Application of Kaolin as a Pozzolanic Additive. Construction Building Mater. 40, 783-792. doi:10.1016/j.conbuildmat.2012.11.065

Xu, J., Morris, P. J., Liu, J., and Holden, J. (2018). PEATMAP: Refining Estimates of Global Peatland Distribution Based on a Meta-Analysis. Catena 160, 134-140. doi:10.1016/j.catena.2017.09.010

Yamaguchi, H., and Miyazaki, M. (2014). Refolding Techniques for Recovering Biologically Active Recombinant Proteins from Inclusion Bodies. Biomolecules 4, 235-251. doi:10.3390/biom4010235

Zulkifley, M. T. M., Ng, T. F., Raj, J. K., Hashim, R., Bakar, A. F. A., Paramanthan, S., et al. (2014). A Review of the Stabilization of Tropical lowland Peats. Bull. Eng. Geol. Environ. 73, 733-746. doi:10.1007/s10064-013-0549-5

Zulkifley, M. T. M., Ng, T. F., Raj, J. K., Hashim, R., Ghani, A., Shuib, M. K., et al. (2013). Definitions and Engineering Classifications of Tropical lowland Peats. Bull. Eng. Geol. Environ. 72, 547-553. doi:10.1007/s10064-013-0520-5

Conflict of Interest: The authors declare that the research was conducted in the absence of any commercial or financial relationships that could be construed as a potential conflict of interest.

Copyright (c) 2021 Gowthaman, Chen, Nakashima and Kawasaki. This is an openaccess article distributed under the terms of the Creative Commons Attribution License (CC BY). The use, distribution or reproduction in other forums is permitted, provided the original author(s) and the copyright owner(s) are credited and that the original publication in this journal is cited, in accordance with accepted academic practice. No use, distribution or reproduction is permitted which does not comply with these terms. 